\title{
Genomic testing in pediatric epilepsy
}

\author{
Drew M. Thodeson ${ }^{1}$ and Jason Y. Park ${ }^{2,3}$ \\ ${ }^{1}$ Department of Pediatrics, ${ }^{2}$ Department of Pathology, ${ }^{3}$ Eugene McDermott Center for Human Growth \\ and Development, UT Southwestern Medical Center, Dallas, Texas 75235, USA
}

Abstract Genomic testing has become routine in the diagnosis and management of pediatric patients with epilepsy. In a single test, hundreds to thousands of genes are examined for DNA changes that may not only explain the etiology of the patient's condition but may also inform management and seizure control. Clinical genomic testing has been in clinical practice for less than a decade, and because of this short period of time, the appropriate clinical use and interpretation of genomic testing is still evolving. Compared to the previous era of single-gene testing in epilepsy, which yielded a diagnosis in $<5 \%$ of cases, many clinical genomic studies of epilepsy have demonstrated a clinically significant diagnosis in $30 \%$ or more of patients tested. This review will examine key studies of the past decade and indicate the clinical scenarios in which genomic testing should be considered standard of care.

Corresponding author: jaspar@childrens.com

(C) 2019 Thodeson and Park This article is distributed under the terms of the Creative Commons Attribution-NonCommercial

License, which permits reuse and redistribution, except for commercial purposes, provided that the original author and source are credited.

Published by Cold Spring Harbor Laboratory Press

doi:10.1101/mcs.a004135

\section{INTRODUCTION}

Epilepsy occurs at a frequency of four to eight individuals per 1000 in the United States (Helmers et al. 2015; Gupta et al. 2016). Overall health-care costs for patients with epilepsy are proportional to the number of epileptic episodes with a threefold higher cost in patients with one or more seizures per week compared to individuals with less than one seizure per year (Gupta et al. 2016). Our knowledge of the various causes of epilepsy is still mostly unknown with approximately six out of 10 patients with unknown etiology (Hauser and Kurland 1975; Hauser et al. 1996). Frequently, there is a diagnostic odyssey undertaken to find the etiology including neurodiagnostics, neuroimaging, and metabolic and genetic testing.

With the advent of clinical genomic testing 10 years ago, physicians were empowered to progress from sequencing single genes in serial to sequencing hundreds to thousands of genes in parallel (Evans et al. 2017). Indeed, genomic tests are not single tests but rather an aggregate of millions of tests comprised of individual nucleotide positions. The quick adoption of clinical genomic testing was accomplished because defects in many different genes result in the same clinical presentation; similarly, a single defective gene can exhibit many different phenotypes (Novotny 2017). The prior paradigm of sequentially testing individual genes has a low diagnostic yield and infrequently provides a genetic explanation for a clinical diagnosis. Single-gene testing is a time-consuming and expensive process that is no longer practical in the evaluation of patients with epilepsy (Wang et al. 2014). The capability to rapidly investigate multiple genes in parallel has solved diagnostic odysseys for many patients and families (Mroch et al. 2012). Still, it is unclear to most clinicians when to order genomic testing. The most recent guideline endorsed by the International League Against Epilepsy was published in 2010 and concludes, "... because the field is moving rapidly, with new information emerging practically every day, we present a framework for considering the clinical utility of genetic testing that can be applied to many different syndromes and 
clinical contexts. Given the current state of knowledge, genetic testing has high clinical utility in few clinical contexts, but in some of these it carries implications for daily clinical practice" (Ottman et al. 2010).

In this review, we will discuss the most commonly used genomic tests in clinical practice as it relates to epilepsy. We will also discuss the limitations to and pitfalls of genomic testing. Finally, we will discuss the potential cost-effectiveness of integrating genomic testing into routine clinical practice and present an operational approach for utilizing genomic testing.

\section{TYPES OF GENOMIC TESTING}

\section{Microarray}

Since the early 2000s, chromosomal microarray analysis (CMA) has been available for genome-wide analysis. CMA techniques use nucleic acid probes to detect copy-number changes (gains and deletions) across the genome. When these copy-number changes occur in regions with genes, the loss or gain in gene function may be predicted. In one pediatric epilepsy study, 226 pediatric patients with first-time epilepsy were examined by CMA (Vlaskamp et al. 2017). A clinically relevant copy-number variant was detected in $11 \%$ of patients $(n=24)$. The variants detected had a wide range in size from $88 \mathrm{~kb}$ to $21.1 \mathrm{Mbp}$. In another pediatric epilepsy study, 805 patients underwent CMA explaining $5 \%$ of cases $(n=40)$; the variants in this study ranged in size from $18 \mathrm{~kb}$ to $142 \mathrm{Mbp}$ (Olson et al. 2014). In one of the largest studies $(n=1255)$ of patients with epilepsy, $10.9 \%$ of patients had a pathogenic variant, and an additional $1.7 \%$ of patients had a copy-number variant that was deemed to be possibly pathogenic (Coppola et al. 2019). With a diagnostic yield of 5\%-13\%, CMA is a useful and sometimes critical test in the genetic diagnosis of epilepsy.

The copy-number information from microarrays can now be derived from some genomic DNA sequencing tests; thus, a single DNA test can identify both single-nucleotide variants and larger deletions of exons or whole genes. In a large study of 2603 patients with heterogeneous clinical presentations, reanalysis of exome data for copy-number variations identified a variant relevant to the patient's phenotype in $4.7 \%(n=123)$ of cases; the variant sizes ranged from $727 \mathrm{bp}$ to $15.3 \mathrm{Mbp}$. In a recent study focused on epilepsy, 168 families with epilepsy with negative test results from exome sequencing were reanalyzed using software designed to detect copy-number variation (Tsuchida et al. 2018). The exome data from these families was reanalyzed using software designed to detect copy-number variation. Pathogenic copy-number variants were detected in $10.7 \%$ of patients examined $(n=18)$. Compared to traditional CMA, the exome-derived data yielded a much wider range in size from $260 \mathrm{bp}$ to $45.7 \mathrm{Mbp}$. This study suggests that existing patient data may have expanded utility with the development of new software algorithms. Genome-wide copy-number variation by CMA is still cost-effective to use for clinical diagnosis; however, in the near future, clinical laboratories will likely perform a single next-generation sequencing (NGS) test that assesses both single-nucleotide variation and copy-number variation.

\section{Gene Panel}

In children with epilepsy of early onset or without specific dysmorphic features, targeted NGS panels are the most cost-effective initial test after electroencephalogram and neuroimaging. Diagnostic yield is variable depending on the population sampled. In one of the largest surveys of diagnostic yield, a summary of the clinical experience of a reference lab (GeneDx) examined the diagnostic yield of 8565 patients tested by gene panel $(17,18$, 50, 53, and 70 genes in each panel) and exon-level microarray (December 2011 to December 2015) (Lindy et al. 2018). Overall, a 15.4\% diagnostic yield was achieved in this 
heterogeneous population (average age, $5 \mathrm{yr} 8 \mathrm{mo}$; range, $1 \mathrm{wk}$ to $47 \mathrm{yr}$ ). The study not only identified the most commonly observed genes (MECP2, KCNO2, SCN1A, SCN2A, STXBP1, and $P R R T 2)$, but also identified some genes that were only impacted by de novo variants (CDKL5, STXBP1, SCN8A, GABRA1, and FOXG1).

Studies on more defined populations have shown higher diagnostic yield from genomic testing. In a study of 74 pediatric patients with intractable early-onset epilepsy, a NGS panel of 172 genes demonstrated a 37.8\% diagnostic yield (Rim et al. 2018). The patients in this study had a 7.5 mo mean age of epilepsy; the majority of patients (85.1\%) had epilepsy onset within the first year of life. The $37.8 \%$ diagnostic yield $(n=28)$ was attributed to 17 different genes, with the most frequently affected gene implicated in three cases (STXBP1). A separate study using a 46-gene NGS panel testing 216 patients with epilepsies ranging from neonatal seizures to epileptic encephalopathies (Møller et al. 2016). A disease-causing variant was identified in $23 \%(n=49)$ of patients. The cohort consisted of both pediatric and adult patients with $23 \%$ of $>18 \mathrm{yr}$ of age. Of the 46 genes tested, 19 had disease-causing variants. Additionally, genes with disease-causing variants were sometimes implicated in more than one patient. The most frequently implicated gene was SCN1A $(n=12)$. The other genes that were implicated in more than one patient were CDKL5 $(n=4), \operatorname{GABRA} 1(n=2)$, GABRB3 $(n=2), \operatorname{KCNQ2}(n=4), \operatorname{SCN} 2 A(n=6), \operatorname{SCN} 8 A(n=3), \operatorname{SLC} 2 A 1(n=3)$, and STXBP1 $(n=4)$. Nine additional genes were each implicated only once each. Neonatal-onset epilepsies (57\%) followed by epileptic encephalopathies (32\%) were most frequently diagnostic. Interestingly, in this study only $3 \%$ of cases reported had a variant of uncertain significance (VUS), whereas other studies have identified a VUS in $>30 \%$ of cases (Lindy et al. 2018; SoRelle et al. 2018). This large difference in VUS detection rate probably can be attributed to differences in variant interpretation criteria; the use of recently published standardized interpretation guidelines (Richards et al. 2015) shows a high rate of VUS detection in epilepsy panel studies (SoRelle et al. 2018).

\section{Exome}

In theory, exome studies are comprehensive tests that examine all DNA variants that encode protein. However, in the context of epilepsy, exome studies have overlapping diagnostic yield with gene panels (Wang et al. 2014). A more recent exome study of epileptic encephalopathies identified de novo variants in 59\% of patients (Heyne et al. 2018). Patients may have unique disease-causing variants that are not present in other family members. In theory, exome testing provides an unbiased approach for investigating rare genetic etiologies. In practice, when selecting clinical exome studies, the limited increase in diagnostic yield over gene panels should be recognized.

A large clinical exome study for patients with epilepsy examined 1131 patients: 314 had seizures and 817 were without seizures (Helbig et al. 2016). Both adult and pediatric patients were participants with the majority of patients examined by trio (proband plus biologic parents) analysis (80.9\%). The remainder were a combination of proband only or proband plus one first-degree relative. The diagnostic yield of clinical exome was $33.4 \%$ for epilepsy patients (105 of 314). In comparison, the nonepilepsy group had a diagnostic yield of $25.9 \%$ (212 of 817). A total of 93 genes were implicated: 21 were found in two or more patients; six genes were seen in three or more patients (KCNQ2, MECP2, FOXG1, IQSEC2, KMT2A, and STXBP1). Of the patients tested, $80 \%$ previously had negative testing by microarray or targeted gene panels. This study was by a reference laboratory, and the authors recognized that the findings in the patients referred to their laboratory may not be generalizable to all patients with epilepsy.

Another approach to exome sequencing is to analytically sequence all coding genes, but only examine and interpret a subset of genes that were related to the patient's epilepsy type 
(Perucca et al. 2017). In 40 consecutive pediatric and adult patients with focal epilepsy, 64 epilepsy-associated genes were analyzed. In this study $12.5 \%$ (5 of 40 patients) had a disease-associated variant; one patient each for a defect in SCN1A, DEPDC5, PCDH19, GABRG2, or NPRL2. The median age of seizure onset of patients with an identified variant was $18 \mathrm{mo}$ (range $8 \mathrm{mo}$ to $18 \mathrm{yr}$ ) versus $18 \mathrm{yr}$ (range $18 \mathrm{mo}$ to $70 \mathrm{yr}$ ) for patients without an identified variant. This study identified a correlation between age of epilepsy onset and the diagnostic yield; patients with onset of epilepsy before the age of $2 \mathrm{yr}$ were more likely to have positive genetic findings.

Building on this concept, a prospective study has focused on the use of genetic testing in children with epilepsy onset at $<3$ yr of age (Berg et al. 2017). This multi-institutional study enrolled 775 patients with a median age of onset of $7.5 \mathrm{mo}$. A subset of 327 patients underwent genetic testing, and $40.4 \%$ received a genetic diagnosis. The study included karyotype, microarrays, epilepsy gene panels, exomes, and mitochondrial panels and other tests. The highest yield test in this study was karyotype ( 26 of $59,44.1 \%)$, followed by exome ( 11 of $33,33.3 \%), 31$ of 114 epilepsy panels (27.2\%), mitochondrial panels ( 4 of $20,20 \%$ ), and microarrays 32 of $188(17 \%)$. The authors concluded that genetic investigation should be part of the initial evaluation of early-onset epilepsy, and testing should be individualized based on the clinical presentation.

A parallel comparison of exome versus conventional genetic testing in 150 pediatric patients with complex neurologic disorders used both conventional diagnostic workup (imaging, biopsies, lumbar punctures, and sequential gene-specific testing) and exome sequencing (trio) (Vissers et al. 2017). The majority of patients $(n=143)$ did not have a family history of neurologic disorders. The most frequent clinical findings in the patients were intellectual disability $(n=78)$, movement disorders $(n=20)$, and neuromuscular disease $(n=8)$. The patients examined by exome sequencing alone had a higher diagnostic yield of $29.3 \%$ compared to the conventional diagnostic workup's yield of $7.3 \%$. The conventional diagnostic workup with sequential single gene sequencing had an average of 4.6 genetic tests performed before reaching a diagnosis. The study also examined diagnostic concordance between exome and conventional workup. Eight patients reached the same diagnosis by either method. Thirty-six patients only had a diagnosis by exome, and three patients only had their diagnosis through conventional diagnostic workup with sequential gene testing. The three patients with a genetic diagnosis missed by exome included a patient with 9-bp duplication event, a repeat expansion in FMR1, and a mosaic 27-Mbp duplication of Chromosome 7. This study is unique because it examines the role of exome testing in comparison to conventional diagnostic modalities. Future studies on exome or other advanced genomic technologies should utilize this design of direct comparison with conventional diagnostic modalities.

\section{TECHNICAL LIMITATIONS AND PITFALLS}

An important concept to consider when selecting any genomic test is that there is only a subset of genes that is clinically useful to analyze. Of the greater than 18,000 genes that encode protein, less than 6000 currently have specific associations with human disease. Although both coding and noncoding variants are identified, the clinical analysis is limited to variants near or in genes with known association with human disease. To put this into perspective, of the three billion bases examined in whole-genome testing, $<1 \%$ of the data is currently useful for clinical diagnosis. Indeed, the technology for sequencing DNA has advanced to the point that the ability to test DNA outpaces the ability to ability to deliver affordable and clinically meaningful interpretations that are relevant to the patient's care. 
Other limitations of genomic tests include incidental findings, nonpaternity, and analytical failures. Genomic tests may uncover incidental (secondary) findings of significant consequence to the future health and unrelated to the patient's current health (Green et al. 2013; Kalia et al. 2017). Incidental findings are estimated to be in 1\%-3\% of the U.S. population and include adult-onset diseases such as cancer, cardiac abnormalities, or neurodegenerative disease (Dorschner et al. 2013). In addition to genetic findings unrelated to the patient's current health, genetic tests may reveal nonpaternity. Nonpaternity varies widely depending in studies with a median rate of $3.7 \%$ (range $0.8 \%$ to 30\%) (Bellis et al. 2005). Limitations of incidental findings and nonpaternity can be mitigated by careful pretest counseling of the patient and/or family.

Analytical inconsistencies or failures are a sign of the relative newness of the technology. The quality metrics for standardization of testing is still in flux. Specifically, for epilepsy testing, the content (genes examined) has been in constant evolution. New genetic discoveries may increase the number of relevant genes to be tested. Thus, there may be variation in the exact genes examined by different laboratories. Alternatively, a laboratory may provide testing by using an exome kit; however, laboratories may analyze all genes in the exome or only examine a small subset of genes that they deem to be clinically relevant.

Analytical quality metrics are also evolving in terms of how "deeply" genomic tests sequence a target. Each nucleotide position needs 40 reads per nucleotide position (40x) to achieve a $95 \%$ confidence of a heterozygous change (Meynert et al. 2013, 2014). The commonly used target for minimum reads of data is 20 (20x); however, this is predicted to miss $5 \%-15 \%$ of heterozygous variants, which could be a critical error in rare disease detection (Meynert et al. 2013). In studies of both exome (Park et al. 2015) and whole-genome (Dewey et al. 2014) sequencing, small inadequacies in coding nucleotide coverage can lead to clinically significant deficiencies in analysis of important genes.

Another quality consideration is confirmation by Sanger sequencing. The quality of NGS is improving and some have suggested that Sanger confirmation is no longer necessary (Beck et al. 2016). However, other studies have shown that although NGS quality is quite high ( $>90 \%$ of variants identified), there are specific analytical scenarios in which Sanger confirmation is necessary (Strom et al. 2014; Baudhuin et al. 2015). From the perspective of clinical providers and patients, there should be a preference for laboratories that either perform Sanger confirmation of all clinically important variants or otherwise have established criteria for when Sanger confirmation is necessary.

A future consideration for genomic testing is the need for longitudinal reinterpretations. For example, a patient presenting with intractable epilepsy at $2 \mathrm{yr}$ of age may have a genomic test performed and VUSs with or without clinical significance may be identified. Any variants that are identified are interpreted at the time of the testing, but these variants can also be reinterpreted with the passage of time and the development of the medical literature. Periodic reanalysis of existing genetic data is not performed by all clinical laboratories. However, studies have shown that genetic diagnoses may significantly change over time (Costain et al. 2018; Hiatt et al. 2018; Mersch et al. 2018; SoRelle et al. 2018). The types of diagnostic changes include not only upgrades from uncertain diagnosis to disease-causative diagnosis, but also can include downgrades from pathogenic diagnoses to benign findings. The physicians who use genomic tests must communicate with their patients that the interpretation of genetic variants may change with advances in medical knowledge. Furthermore, as pediatric patients reach majority status and seek information on the risk of future-onset diseases (e.g., neurodegenerative, cancer), then an exome data set should be made available for further reanalysis for adult-onset disorders. Clinical care providers who order genomic testing on their patients should be familiar with a basic checklist of quality considerations for clinical genomic laboratories (Table 1). 
Table 1. Quality checklist in clinical laboratory and test selection

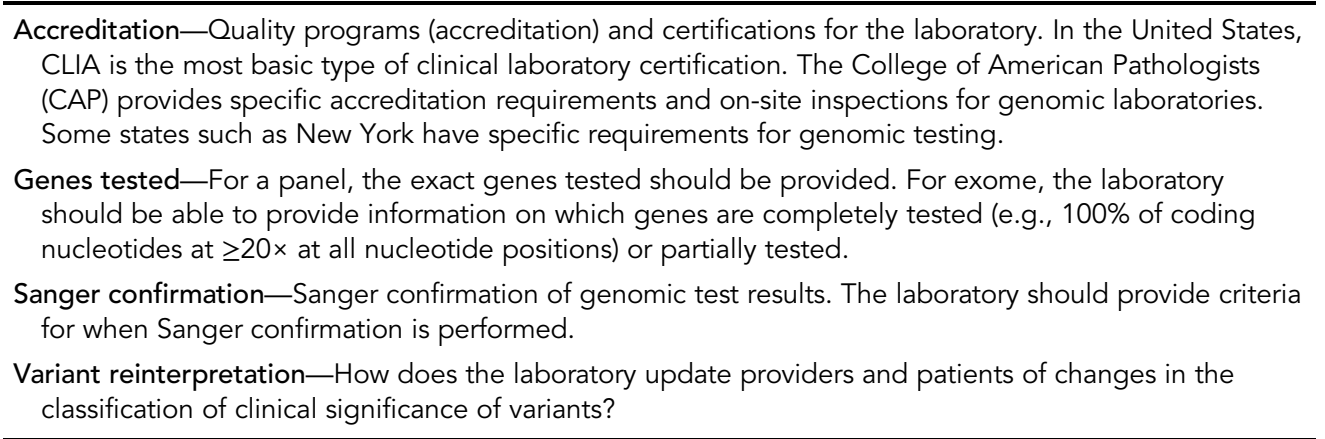

\section{TREATMENT IMPLICATIONS}

Although genomic testing is predominantly diagnostic, there are treatment implications in some cases. In a retrospective review of 50 patients with exome testing, $48 \%$ had a genetic diagnosis; the majority of management changes from those diagnoses were prognostic or informative for family planning (Nolan and Carlson 2016). However, there were five genes in patients that involved medication changes: CACNA1A (acetazolamide); NSD1 (discontinued mitochondrial cocktail); SCN1A (avoid carbamazepine, lamotrigine, or vigabatrin); SLC13A5 (citrate transport defect; acetazolamide improved some symptoms); and WDR45 (associated sleep concerns; started clonidine). In another series, a patient was discovered to have compound heterozygosity of pathogenic variants in PNPO (pyridoxamine 5-prime-phosphate oxidase) and was placed on oral vitamin therapy (Fung et al. 2017). Importantly, although the patient was seizure-free on a combination of pyridoxal 5-phosphate and valproate, his preexisting severe developmental delays and visual deficits did not improve. Beyond vitamin-responsive epilepsies, NGS panels are helpful in identifying other diagnoses that have emerging evidence for precision medicine including GLUT-1 spectrum disorders, certain sodium and potassium channelopathies, and other rare inborn errors of metabolism (e.g., cerebral creatine deficiency syndromes) (Table 2; Dang and Silverstein 2017).

\section{COST-EFFECTIVENESS}

In Canada, a cost study model, CAUSES (clinical assessment of the utility of sequencing and evaluation for service) examined service delivery models of singleton (proband only) exome and trio exome sequencing (Dragojlovic et al. 2018). The goal of the model is to provide expert consultation in suspected monogenic disorders in British Columbia in efforts to define clinical utility of exome and genome sequencing. The clinical delivery service model in CAUSES includes clinical consultation with a committee of genetics specialists, test facilitation in a contract research laboratory, and analysis of the research laboratory data by the CAUSES team. Any clinically significant variants were confirmed by Sanger sequencing in a hospital-based clinical laboratory and subsequently reported in the medical record and discussed with families. The CAUSES study included analysis of 500 families. In their model simulation using data from their CAUSES delivery of care, the cost assessment (including all clinical services) was $\$ 6437$ versus $\$ 2576$ for trio and singleton, respectively. Importantly, this study modeled a cost per positive diagnosis and estimated that the cost per positive diagnosis was $\$ 19,340$ and $\$ 10,700$ for trio and singleton, respectively. This 
Table 2. Genes and syndromes with therapeutic implications

\begin{tabular}{|c|c|c|}
\hline Gene & Syndrome(s) & Therapeutic implication \\
\hline ALDH7A1 & Epilepsy, pyridoxine-dependent & Pyridoxine (Yang et al. 2014) \\
\hline CACNA1A & Calcium channelopathy associated with ataxia & Acetazolamide (Spacey 1993; Nolan and Carlson 2016) \\
\hline CHRNA2 & Autosomal dominant nocturnal frontal lobe epilepsy & Nicotine (Fox et al. 2018) \\
\hline CHRNA4 & Autosomal dominant nocturnal frontal lobe epilepsy & $\begin{array}{l}\text { Nicotine (Pavlakis and Douglass 2015; Fox et al. 2018; } \\
\text { Oates et al. 2018) }\end{array}$ \\
\hline CHRNB2 & Epilepsy, nocturnal frontal lobe, 3 & $\begin{array}{l}\text { Nicotine (Zerem et al. 2013; Sieciechowicz and Kohrman } \\
\text { 2015) }\end{array}$ \\
\hline EPM2A & Epilepsy, progressive myoclonic 2A (Lafora) & $\begin{array}{l}\text { Avoid sodium channel blockers (lamotrigine and phenytoin) } \\
\text { (Jansen and Andermann 1993) }\end{array}$ \\
\hline GRIN2A & $\begin{array}{l}\text { Epileptic encephalopathy, epileptic-aphasia syndrome (Landau- } \\
\text { Kleffner syndrome, lectrical status epilepticus during sleep) }\end{array}$ & Memantine (Pierson et al. 2014) \\
\hline KCNQ2 & Epileptic encephalopathy, early infantile, 7 & $\begin{array}{l}\text { Carbamazepine, oxcarbazepine, phenytoin (Pisano et al. } \\
\text { 2015; Sands et al. 2016) }\end{array}$ \\
\hline KCNQ3 & Seizures, benign neonatal, 2 & Phenobarbital, carbamazepine (Sands et al. 2016) \\
\hline KCNT1 & $\begin{array}{l}\text { Epilepsy, nocturnal frontal lobe, } 5 \\
\text { Epileptic encephalopathy, early infantile, } 14\end{array}$ & Quinidine $^{a}$ (Mikati et al. 2015) \\
\hline $\mathrm{PCDH} 19$ & Epileptic encephalopathy, early infantile, 9 & $\begin{array}{l}\text { Ganaxolone (Farnaes et al. 2018); stiripentol (Trivisano et al. } \\
\text { 2015) }\end{array}$ \\
\hline PNPO & Pyridoxamine 5'-phosphate oxidase deficiency & $\begin{array}{l}\text { Pyridoxal-5-phosphate (vitamin B } 6 \text { ) (Mills et al. 2014; Guerin } \\
\text { et al. 2015) }\end{array}$ \\
\hline POLG & $\begin{array}{l}\text { Mitochondrial DNA depletion syndromes } 4 \mathrm{~A}, 4 \mathrm{~B} \\
\text { Mitochondrial recessive ataxia syndrome } \\
\text { Progressive external opthalmoplegias }\end{array}$ & Avoid sodium valproate (Stewart et al. 2010) \\
\hline PRRT2 & $\begin{array}{l}\text { Convulsions, familial infantile, with paroxysmal choreoathetosis } \\
\text { Episodic kinesigenic dyskinesia } 1 \\
\text { Seizures, benign familial infantile, } 2\end{array}$ & Carbamazepine (Li et al. 2013; Dale et al. 2014) \\
\hline SCN1A & $\begin{array}{l}\text { Epilepsy, generalized, with febrile seizure plus, type } 2 \\
\text { Epileptic encephalopathy, early infantile, } 6 \text { (Dravet) } \\
\text { Febrile seizures, familial, 3A } \\
\text { Migraine, familial hemiplegic, } 3\end{array}$ & $\begin{array}{l}\text { Bromide (Lotte et al. 2012; Shi et al. 2016); stiripentol } \\
\text { (Balestrini and Sisodiya 2017); avoid sodium channel } \\
\text { blockers (lamotrigine and phenytoin) (Nolan and Carlson } \\
\text { 2016; Shi et al. 2016) }\end{array}$ \\
\hline SCN2A & $\begin{array}{l}\text { Epileptic encephalopathy, early infantile, } 11 \\
\text { Seizures, benign familial infantile, } 3\end{array}$ & $\begin{array}{l}\text { High-dose phenytoin (Dilena et al. 2017; Flor-Hirsch et al. } \\
\text { 2018) }\end{array}$ \\
\hline SCN8A & $\begin{array}{l}\text { Epileptic encephalopathy, early infantile, } 13 \\
\text { Seizures, benign familial infantile, } 5\end{array}$ & $\begin{array}{l}\text { High-dose phenytoin (Barker et al. 2016; Boerma et al. } \\
\text { 2016) }\end{array}$ \\
\hline SLC13A5 & Epileptic encephalopathy, early infantile, 25 & $\begin{array}{l}\text { Acetazolamide (Nolan and Carlson 2016); stiripentol } \\
\text { (Alhakeem et al. 2018) }\end{array}$ \\
\hline SLC2A1 & GLUT1 deficiency syndrome & $\begin{array}{l}\text { Ketogenic diet, triheptanoin (Pascual et al. 2014; Koch and } \\
\text { Weber 2018) }\end{array}$ \\
\hline TSC1 & Tuberous sclerosis- 1 & Vigabatrin, everolimus (Curatolo et al. 2018) \\
\hline TSC2 & Tuberous sclerosis-2 & Vigabatrin, everolimus (Curatolo et al. 2018) \\
\hline
\end{tabular}

Adapted from Dang and Silverstein 2017.

${ }^{a}$ Quinidine may be ineffective (Mullen et al. 2018).

is not the first cost analysis study of exome testing, but it is one of the more comprehensive studies that takes into account not only the cost of the test, but also the cost of each of the clinical components that associated with the test such as genetic counseling, travel, and other costs. The authors report that only $4 \%$ of the patients in their study had incidental findings; however, the downstream cost of incidental findings reported to patients was not calculated or modeled. 
In Australia, Tan et al. (2017) examined the utility of singleton exome sequencing in pediatric patients with suspected monogenic disorder who had not had previous genetic testing. Forty-four children were enrolled in this prospective study and the diagnostic yield within this population was $52 \%$. In their exome analysis only a subset of 3203 genes were examined. A clinical history of epilepsy was not a specific focus of their study, but many patients had a CNS phenotype characterized by intellectual disability. Overall, the authors projected the total health costs (including medical consultations, neurophysiological testing, diagnostic testing, travel, etc.) of these 44 patients to be $>\$ 430,000$ ( $\$ 9772$ per patient). In terms of diagnostic testing, the authors proposed four different diagnostic models: (1) standard management without exome; (2) standard management with exome; (3) exome at initial tertiary care appointment; and (4) exome at initial genetics appointment. Within their model, the lowest cost per diagnosis cost was found with exome sequencing at initial tertiary care management ( $\$ 7526$ per diagnosis) followed by exome at first genetics visit $(\$ 10,225$ per diagnosis). Importantly, there was no predicted savings by performing exome after a standard diagnostic workup, suggesting exome sequencing may be a reasonable first-line test in suspected pediatric monogenic disorders.

Cost-effectiveness of genomic testing has been examined specifically for patients with severe epilepsies of infancy (Howell et al. 2018). An incremental cost-effectiveness ratio was examined for patients with epilepsy diagnosed from 2011 to 2013. Patients were included when meeting the criteria of seizure onset before $18 \mathrm{mo}$ of age, frequent seizures, epileptiform EEG, and failure of two or more antiepileptic drugs. As part of routine care, genetic testing was only performed when MRI and EEG were negative. The genetic testing included gene sequencing panels (39 to 65 genes), chromosomal analysis, and exome and wholegenome sequencing. The particular exome analysis in this study was exome sequencing with analysis and interpretation limited to 341 genes known to be associated with infantile-onset epilepsy. The overall diagnostic yield for genetic testing was 54\% (62 of 114). Cost-effectiveness was then modeled using only the exome data to calculate the cost per diagnosis if the exome were performed earlier or later in the patient's care. The baseline model used no exome testing and had a diagnostic yield of $45 \%$ with a total cost of $\$ 661,103$ and an average cost per diagnosis $\$ 16,951$. In contrast when exome was used early in the patient's care (after MRI, microarray, routine blood, and urine metabolic tests), a diagnostic yield of $53 \%$ was achieved with overall lower cost- $\$ 445,597$ total cost and an average cost per diagnosis of $\$ 9904$. The least cost-effective model was using exome as the last diagnostic modality- $\$ 738,136$ total cost and an average cost per diagnosis of $\$ 15,378$. The investigators concluded that exome testing is clinically important and cost-effective in evaluation of early-onset intractable epilepsy. Other studies have noted cost savings ranging from $\$ 2000$ to $\$ 7000$ per diagnosis when exome sequencing is considered early in the diagnostic pathway (Riechmann et al. 2015; Vissers et al. 2017). A recent meta-analysis identified the diagnostic yield and cost-effectiveness of CMA, gene panels, and exome for patients with epilepsy (Sánchez Fernández et al. 2019). In this study, exome had the highest diagnostic yield of $32 \%$ (range $22 \%-44 \%$ ), followed by gene panels (23\%; 18\%-29\%), and CMA (8\%; $6 \%-12 \%)$. Based on these diagnostic yields, the most cost-effective test was gene panel testing with an incremental cost-effectiveness ratio of $\$ 15,848$ per diagnosis, followed by exome with $\$ 34,500$ per diagnosis. The authors identified the most cost-effective strategy as a gene panel, followed by CMA, then exome. The meta-analysis did not support CMA as a first-tier diagnostic test for patients with epilepsy.

There is inconsistent insurance coverage of genetic testing in the United States. Indeed, the evidence used by insurers in the United States for coverage of genetic testing is different than evidence used for other medical tests such as radiology and drug approval (Chambers et al. 2017). In a systematic study, five insurance payers were examined for a total of 55 relevant coverage policies relevant to 313 gene panels. Clinical guidelines were cited in $84 \%$ of 


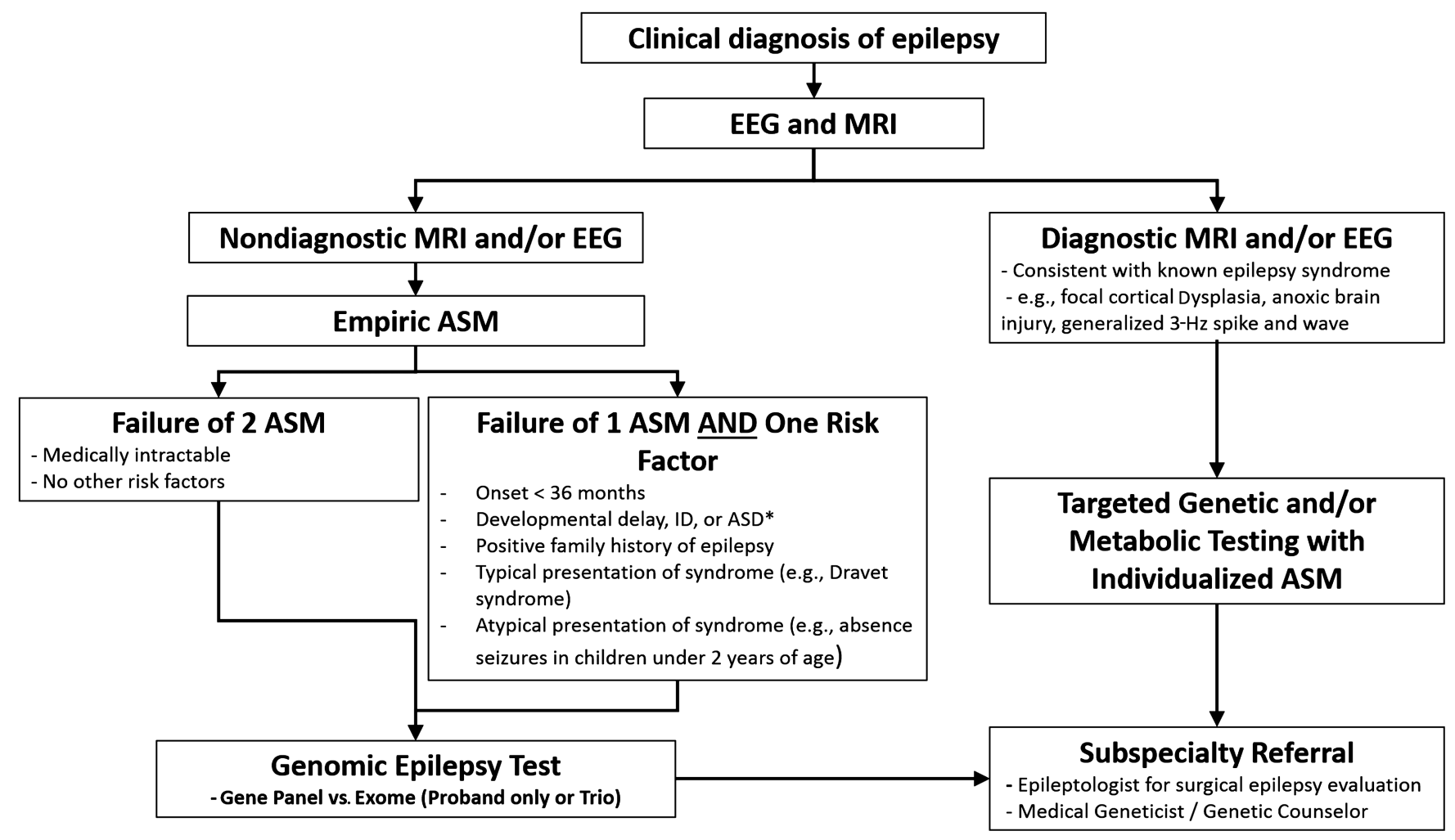

Figure 1. Clinical pathway for genomic evaluation of pediatric epilepsy. A clinical pathway for genomic management of pediatric patients with epilepsy begins with a clinical diagnosis of epilepsy by a neurologist. This is followed by routine EEG and brain MRI. If the patient has a diagnostic MRI and/or EEG, the patient proceeds to targeted testing and individualized ASM followed by subspecialty referral for further management by epileptologists and/or genetic specialists. If the MRI and/or EEG are not diagnostic, the patient is started on an empiric course of ASM. If the patient has either two failures of empiric therapy or one failure of empiric therapy and an additional risk factor, then the patient has genomic epilepsy testing performed (gene panel vs. exome [proband-only or trio]). After genomic testing, the patient is then referred to subspecialty consultation with an epileptologist and/or genetic specialist. *Standard of care testing for children with developmental delay includes CMA and fragile X (if male). (ASD) Autism spectrum disorder, (ASM) antiseizure medication, (CMA) chromosomal microarray, (EEG) electroencephalogram, (ID) intellectual disability, (MRI) magnetic resonance imaging.

policies (range 73\%-100\%). Cost-effectiveness and budget impact studies were rarely cited by payers (5\% of policies with a range of $0 \%-7 \%$ ). Individual clinical studies were cited in $69 \%$ of policies (range $50 \%-87 \%$ ). The reason for inconsistent coverage is multifactorial, including evolving techniques and technologies, lack of long-term clinical information on rare genetic disorders, and difficulty defining the clinical validity and utility of gene panel tests. The inconsistent financial coverage of genomic testing for patients with epilepsy remains a major obstacle to clinical implementation in the United States.

\section{CONCLUSIONS}

Genomic testing in epilepsy is evolving diagnostically and there are emerging therapeutic considerations for a number of genetic epilepsy syndromes. However, the literature supports that a thorough clinical assessment is needed prior to evaluating a patient by a genomic test. 
Competing Interest Statement

The authors have declared no competing interest.
Previous studies have confirmed that diagnostic yields in certain epilepsy populations lead to high diagnostic rates and are cost-effective in comparison to conventional diagnostic modalities and prior methods of serial sequencing of individual genes.

In the current era of clinical medicine, which is characterized by financial pressures and cost sensitivity, clinical practitioners need to be judicious in cost of their patient management. Prior authorization has become a routine step in the process for obtaining genomic testing for patients. From the perspective of cost mitigation, our clinical practice has implemented a clinical pathway for genomic testing in pediatric epilepsy (Fig. 1). Moreover, there is mounting evidence that genomic testing in intractable epilepsy with childhood onset may lead to precision therapies and is becoming standard practice at most tertiary care institutions. Indeed, we stipulate that these genetic testing methods will lead to more streamlined diagnostic algorithm and ultimately provide life-changing precision medicine to patients with epilepsy.

\section{REFERENCES}

Alhakeem A, Alshibani F, Tabarki B. 2018. Extending the use of stiripentol to SLC13A5-related epileptic encephalopathy. Brain Dev 40: 827-829. doi:10.1016/j.braindev.2018.05.020

Balestrini S, Sisodiya SM. 2017. Audit of use of stiripentol in adults with Dravet syndrome. Acta Neurol Scand 135: 73-79. doi:10.1111/ane.12611

Barker BS, Ottolini M, Wagnon JL, Hollander RM, Meisler MH, Patel MK. 2016. The SCN8A encephalopathy mutation p.lle1327Val displays elevated sensitivity to the anticonvulsant phenytoin. Epilepsia 57: 14581466. doi:10.1111/epi.13461

Baudhuin LM, Lagerstedt SA, Klee EW, Fadra N, Oglesbee D, Ferber MJ. 2015. Confirming variants in nextgeneration sequencing panel testing by Sanger sequencing. J Mol Diagn 17: 456-461. doi:10.1016/j .jmoldx.2015.03.004

Beck TF, Mullikin JC, Program NCS, Biesecker LG. 2016. Systematic evaluation of sanger validation of nextgeneration sequencing variants. Clin Chem 62: 647-654. doi:10.1373/clinchem.2015.249623

Bellis MA, Hughes K, Hughes S, Ashton JR. 2005. Measuring paternal discrepancy and its public health consequences. J Epidemiol Community Health 59: 749-754. doi:10.1136/jech.2005.036517

Berg AT, Coryell J, Saneto RP, Grinspan ZM, Alexander JJ, Kekis M, Sullivan JE, Wirrell EC, Shellhaas RA, Mytinger JR, et al. 2017. Early-life epilepsies and the emerging role of genetic testing. JAMA Pediatr 171: 863-871. doi:10.1001/jamapediatrics.2017.1743

Boerma RS, Braun KP, van den Broek MP, van Berkestijn FM, Swinkels ME, Hagebeuk EO, Lindhout D, van Kempen M, Boon M, Nicolai J, et al. 2016. Remarkable phenytoin sensitivity in 4 children with SCN8A-related epilepsy: a molecular neuropharmacological approach. Neurotherapeutics 13: 192-197. doi:10 $.1007 / \mathrm{s} 13311-015-0372-8$

Chambers JD, Saret CJ, Anderson JE, Deverka PA, Douglas MP, Phillips KA. 2017. Examining evidence in U.S. payer coverage policies for multi-gene panels and sequencing tests. Int J Technol Assess Health Care 33: 534-540. doi:10.1017/S0266462317000903

Coppola A, Cellini E, Stamberger H, Saarentaus E, Cetica V, Lal D, Djémié T, Bartnik-Glaska M, Ceulemans B, Helen Cross J, et al. 2019. Diagnostic implications of genetic copy number variation in epilepsy plus. Epilepsia 60: 689-706. doi:10.1111/epi.14683

Costain G, Jobling R, Walker S, Reuter MS, Snell M, Bowdin S, Cohn RD, Dupuis L, Hewson S, MercimekAndrews $S$, et al. 2018. Periodic reanalysis of whole-genome sequencing data enhances the diagnostic advantage over standard clinical genetic testing. Eur J Hum Genet 26: 740-744. doi:10.1038/s41431-0180114-6

Curatolo P, Nabbout R, Lagae L, Aronica E, Ferreira JC, Feucht M, Hertzberg C, Jansen AC, Jansen F, Kotulska $\mathrm{K}$, et al. 2018. Management of epilepsy associated with tuberous sclerosis complex: updated clinical recommendations. Eur J Paediatr Neurol 22: 738-748. doi:10.1016/j.ejpn.2018.05.006

Dale RC, Gardiner A, Branson JA, Houlden H. 2014. Benefit of carbamazepine in a patient with hemiplegic migraine associated with PRRT2 mutation. Dev Med Child Neurol 56: 910. doi:10.1111/dmcn.12396

Dang LT, Silverstein FS. 2017. Drug treatment of seizures and epilepsy in newborns and children. Pediatr Clin North Am 64: 1291-1308. doi:10.1016/j.pcl.2017.08.007

Dewey FE, Grove ME, Pan C, Goldstein BA, Bernstein JA, Chaib H, Merker JD, Goldfeder RL, Enns GM, David $\mathrm{SP}$, et al. 2014. Clinical interpretation and implications of whole-genome sequencing. JAMA 311: 10351045. doi:10.1001/jama.2014.1717 
Dilena R, Striano P, Gennaro E, Bassi L, Olivotto S, Tadini L, Mosca F, Barbieri S, Zara F, Fumagalli M. 2017. Efficacy of sodium channel blockers in SCN2A early infantile epileptic encephalopathy. Brain Dev 39: 345-348. doi:10.1016/j.braindev.2016.10.015

Dorschner MO, Amendola LM, Turner EH, Robertson PD, Shirts BH, Gallego CJ, Bennett RL, Jones KL, Tokita MJ, Bennett JT, et al. 2013. Actionable, pathogenic incidental findings in 1,000 participants' exomes. Am J Hum Genet 93: 631-640. doi:10.1016/j.ajhg.2013.08.006

Dragojlovic N, Elliott AM, Adam S, van Karnebeek C, Lehman A, Mwenifumbo JC, Nelson TN, du Souich C, Friedman JM, Lynd LD. 2018. The cost and diagnostic yield of exome sequencing for children with suspected genetic disorders: a benchmarking study. Genet Med 20: 1013-1021. doi:10.1038/gim.2017 .226.

Evans JP, Powell BC, Berg JS. 2017. Finding the rare pathogenic variants in a human genome. JAMA 317: 1904-1905. doi:10.1001/jama.2017.0432

Farnaes L, Hildreth A, Sweeney NM, Clark MM, Chowdhury S, Nahas S, Cakici JA, Benson W, Kaplan RH, Kronick R, et al. 2018. Rapid whole-genome sequencing decreases infant morbidity and cost of hospitalization. NPJ Genom Med 3: 10. doi:10.1038/s41525-018-0049-4

Flor-Hirsch H, Heyman E, Livneh A, Reish O, Watemberg N, Litmanovits I, Ben Sason Lilli A, Lev D, Lerman Sagie T, Bassan H. 2018. Lacosamide for SCN2A-related intractable neonatal and infantile seizures. Epileptic Disord 20: 440-446.

Fox J, Thodeson D, Dolce A. 2018. Epilepsy and neuronal nicotinic acetylcholine receptor gene variants-is nicotine a precision therapy? American Epilepsy Society Annual Meeting 2018. https://www.aesnet.org/ meetings_events/annual_meeting_abstracts/view/500492

Fung CW, Kwong AK, Wong VC. 2017. Gene panel analysis for nonsyndromic cryptogenic neonatal/infantile epileptic encephalopathy. Epilepsia Open 2: 236-243. doi:10.1002/epi4.12055

Green RC, Berg JS, Grody WW, Kalia SS, Korf BR, Martin CL, McGuire AL, Nussbaum RL, O'Daniel JM, Ormond KE, et al. 2013. ACMG recommendations for reporting of incidental findings in clinical exome and genome sequencing. Genet Med 15: 565-574. doi:10.1038/gim.2013.73

Guerin A, Aziz AS, Mutch C, Lewis J, Go CY, Mercimek-Mahmutoglu S. 2015. Pyridox(am)ine-5-phosphate oxidase deficiency treatable cause of neonatal epileptic encephalopathy with burst suppression: case report and review of the literature. J Child Neurol 30: 1218-1225. doi:10.1177/0883073814550829

Gupta S, Kwan P, Faught E, Tsong W, Forsythe A, Ryvlin P. 2016. Understanding the burden of idiopathic generalized epilepsy in the United States, Europe, and Brazil: an analysis from the National Health and Wellness Survey. Epilepsy Behav 55: 146-156. doi:10.1016/j.yebeh.2015.12.018

Hauser WA, Kurland LT. 1975. The epidemiology of epilepsy in Rochester, Minnesota, 1935 through 1967. Epilepsia 16: 1-66. doi:10.1111/j.1528-1157.1975.tb04721.x

Hauser WA, Annegers JF, Rocca WA. 1996. Descriptive epidemiology of epilepsy: contributions of populationbased studies from Rochester, Minnesota. Mayo Clin Proc 71: 576-586. doi:10.4065/71.6.576

Helbig KL, Farwell Hagman KD, Shinde DN, Mroske C, Powis Z, Li S, Tang S, Helbig I. 2016. Diagnostic exome sequencing provides a molecular diagnosis for a significant proportion of patients with epilepsy. Genet Med 18: 898-905. doi:10.1038/gim.2015.186

Helmers SL, Thurman DJ, Durgin TL, Pai AK, Faught E. 2015. Descriptive epidemiology of epilepsy in the U.S. population: a different approach. Epilepsia 56: 942-948. doi:10.1111/epi.13001

Heyne HO, Singh T, Stamberger H, Abou Jamra R, Caglayan H, Craiu D, De Jonghe P, Guerrini R, Helbig KL, Koeleman BPC, et al. 2018. De novo variants in neurodevelopmental disorders with epilepsy. Nat Genet 50: 1048-1053. doi:10.1038/s41588-018-0143-7

Hiatt SM, Amaral MD, Bowling KM, Finnila CR, Thompson ML, Gray DE, Lawlor JMJ, Cochran JN, Bebin EM, Brothers KB, et al. 2018. Systematic reanalysis of genomic data improves quality of variant interpretation. Clin Genet 94: 174-178. doi:10.1111/cge.13259

Howell KB, Eggers S, Dalziel K, Riseley J, Mandelstam S, Myers CT, McMahon JM, Schneider A, Carvill GL, Mefford HC, et al. 2018. A population-based cost-effectiveness study of early genetic testing in severe epilepsies of infancy. Epilepsia 59: 1177-1187. doi:10.1111/epi.14087

Jansen AC, Andermann E. 1993. Progressive myoclonus epilepsy, Lafora type. In GeneReviews ${ }^{\circledR}$ (ed. Adam $M P$, et al.). University of Washington, Seattle, WA.

Kalia SS, Adelman K, Bale SJ, Chung WK, Eng C, Evans JP, Herman GE, Hufnagel SB, Klein TE, Korf BR, et al. 2017. Recommendations for reporting of secondary findings in clinical exome and genome sequencing, 2016 update (ACMG SF v2.0): a policy statement of the American College of Medical Genetics and Genomics. Genet Med 19: 249-255. doi:10.1038/gim.2016.190

Koch H, Weber YG. 2018. The glucose transporter type 1 (Glut1) syndromes. Epilepsy Behav 91: 90-93. doi:10 .1016/j.yebeh.2018.06.010.

Li HF, Chen WJ, Ni W, Wang KY, Liu GL, Wang N, Xiong ZQ, Xu J, Wu ZY. 2013. PRRT2 mutation correlated with phenotype of paroxysmal kinesigenic dyskinesia and drug response. Neurology 80: 1534-1535. doi:10.1212/WNL.0b013e31828cf7e1 
Lindy AS, Stosser MB, Butler E, Downtain-Pickersgill C, Shanmugham A, Retterer K, Brandt T, Richard G, McKnight DA. 2018. Diagnostic outcomes for genetic testing of 70 genes in 8565 patients with epilepsy and neurodevelopmental disorders. Epilepsia 59: 1062-1071. doi:10.1111/epi.14074

Lotte J, Haberlandt E, Neubauer B, Staudt M, Kluger GJ. 2012. Bromide in patients with SCN1A-mutations manifesting as Dravet syndrome. Neuropediatrics 43: 17-21. doi:10.1055/s-0032-1307454

Mersch J, Brown N, Pirzadeh-Miller S, Mundt E, Cox HC, Brown K, Aston M, Esterling L, Manley S, Ross T. 2018. Prevalence of variant reclassification following hereditary cancer genetic testing. JAMA 320: 1266-1274. doi:10.1001/jama.2018.13152

Meynert AM, Bicknell LS, Hurles ME, Jackson AP, Taylor MS. 2013. Quantifying single nucleotide variant detection sensitivity in exome sequencing. BMC Bioinformatics 14: 195. doi:10.1186/1471-2105-14-195

Meynert AM, Ansari M, FitzPatrick DR, Taylor MS. 2014. Variant detection sensitivity and biases in whole genome and exome sequencing. BMC Bioinformatics 15: 247. doi:10.1186/1471-2105-15-247

Mikati MA, Jiang YH, Carboni M, Shashi V, Petrovski S, Spillmann R, Milligan CJ, Li M, Grefe A, McConkie A, et al. 2015. Quinidine in the treatment of KCNT1-positive epilepsies. Ann Neurol 78: 995-999. doi:10 $.1002 / a n a .24520$

Mills PB, Camuzeaux SS, Footitt EJ, Mills KA, Gissen P, Fisher L, Das KB, Varadkar SM, Zuberi S, McWilliam R, et al. 2014. Epilepsy due to PNPO mutations: genotype, environment and treatment affect presentation and outcome. Brain 137: 1350-1360. doi:10.1093/brain/awu051

Møller RS, Larsen LH, Johannesen KM, Talvik I, Talvik T, Vaher U, Miranda MJ, Farooq M, Nielsen JE, Svendsen LL, et al. 2016. Gene panel testing in epileptic encephalopathies and familial epilepsies. Mol Syndromol 7: 210-219. doi:10.1159/000448369

Mroch AR, Flanagan JD, Stein QP. 2012. Solving the puzzle: case examples of array comparative genomic hybridization as a tool to end the diagnostic odyssey. Curr Probl Pediatr Adolesc Health Care 42: 74-78. doi:10.1016/j.cppeds.2011.10.003

Mullen SA, Carney PW, Roten A, Ching M, Lightfoot PA, Churilov L, Nair U, Li M, Berkovic SF, Petrou S, et al. 2018. Precision therapy for epilepsy due to KCNT1 mutations: a randomized trial of oral quinidine. Neurology 90: e67-e72. doi:10.1212/WNL.0000000000004769

Nolan D, Carlson M. 2016. Whole exome sequencing in pediatric neurology patients: clinical implications and estimated cost analysis. J Child Neurol 31: 887-894. doi:10.1177/0883073815627880

Novotny EJ Jr. 2017. Early genetic testing for neonatal epilepsy: when, why, and how? Neurology 89: 880881. doi:10.1212/WNL.0000000000004287

Oates S, Tang S, Rosch R, Lear R, Hughes EF, Williams RE, Larsen LH, Hao Q, Dahl HA, Møller RS. 2018. Incorporating epilepsy genetics into clinical practice: a 360 evaluation. NPJ Genom Med 3: 13. doi:10 .1038/s41525-018-0052-9

Olson H, Shen Y, Avallone J, Sheidley BR, Pinsky R, Bergin AM, Berry GT, Duffy FH, Eksioglu Y, Harris DJ, et al. 2014. Copy number variation plays an important role in clinical epilepsy. Ann Neurol 75: 943-958. doi:10 .1002/ana.24178

Ottman R, Hirose S, Jain S, Lerche H, Lopes-Cendes I, Noebels JL, Serratosa J, Zara F, Scheffer IE. 2010. Genetic testing in the epilepsies-report of the ILAE Genetics Commission. Epilepsia 51: 655-670. doi:10.1111/j.1528-1167.2009.02429.x

Park JY, Clark P, Londin E, Sponziello M, Kricka LJ, Fortina P. 2015. Clinical exome performance for reporting secondary genetic findings. Clin Chem 61: 213-220. doi:10.1373/clinchem.2014.231456

Pascual JM, Liu P, Mao D, Kelly DI, Hernandez A, Sheng M, Good LB, Ma Q, Marin-Valencia I, Zhang X, et al. 2014. Triheptanoin for glucose transporter type I deficiency (G1D): modulation of human ictogenesis, cerebral metabolic rate, and cognitive indices by a food supplement. JAMA Neurol 71: 1255-1265. doi:10 $.1001 /$ jamaneurol.2014.1584

Pavlakis PP, Douglass LM. 2015. Pearls \& oysters: a case of refractory nocturnal seizures: putting out fires without smoke. Neurology 84: e134-e136. doi:10.1212/WNL.0000000000001539

Perucca P, Scheffer IE, Harvey AS, James PA, Lunke S, Thorne N, Gaff C, Regan BM, Damiano JA, Hildebrand MS, et al. 2017. Real-world utility of whole exome sequencing with targeted gene analysis for focal epilepsy. Epilepsy Res 131: 1-8. doi:10.1016/j.eplepsyres.2017.02.001

Pierson TM, Yuan H, Marsh ED, Fuentes-Fajardo K, Adams DR, Markello T, Golas G, Simeonov DR, Holloman C, Tankovic A. 2014. GRIN2A mutation and early-onset epileptic encephalopathy: personalized therapy with memantine. Ann Clin Transl Neurol 1: 190-198. doi:10.1002/acn3.39

Pisano T, Numis AL, Heavin SB, Weckhuysen S, Angriman M, Suls A, Podesta B, Thibert RL, Shapiro KA, Guerrini R, et al. 2015. Early and effective treatment of KCNQ2 encephalopathy. Epilepsia 56: 685-691. doi:10.1111/epi.12984

Richards S, Aziz N, Bale S, Bick D, Das S, Gastier-Foster J, Grody WW, Hegde M, Lyon E, Spector E, et al. 2015. Standards and guidelines for the interpretation of sequence variants: a joint consensus recommendation of the American College of Medical Genetics and Genomics and the Association for Molecular Pathology. Genet Med 17: 405-424. doi:10.1038/gim.2015.30 
Riechmann J, Strzelczyk A, Reese JP, Boor R, Stephani U, Langner C, Neubauer BA, Oberman B, Philippi H, Rochel M, et al. 2015. Costs of epilepsy and cost-driving factors in children, adolescents, and their caregivers in Germany. Epilepsia 56: 1388-1397. doi:10.1111/epi.13089

Rim JH, Kim SH, Hwang IS, Kwon SS, Kim J, Kim HW, Cho MJ, Ko A, Youn SE, Kim J, et al. 2018. Efficient strategy for the molecular diagnosis of intractable early-onset epilepsy using targeted gene sequencing. BMC Med Genomics 11: 6. doi:10.1186/s12920-018-0320-7

Sánchez Fernández I, Loddenkemper T, Gaínza-Lein M, Sheidley BR, Poduri A. 2019. Diagnostic yield of genetic tests in epilepsy: a meta-analysis and cost-effectiveness study. Neurology doi:10.1212/WNL .0000000000006850

Sands TT, Balestri M, Bellini G, Mulkey SB, Danhaive O, Bakken EH, Taglialatela M, Oldham MS, Vigevano F, Holmes GL, et al. 2016. Rapid and safe response to low-dose carbamazepine in neonatal epilepsy. Epilepsia 57: 2019-2030. doi:10.1111/epi.13596

Shi XY, Tomonoh Y, Wang WZ, Ishii A, Higurashi N, Kurahashi H, Kaneko S, Hirose S, Epilepsy Genetic Study Group, Japan. 2016. Efficacy of antiepileptic drugs for the treatment of Dravet syndrome with different genotypes. Brain Dev 38: 40-46. doi:10.1016/j.braindev.2015.06.008

Sieciechowicz D, Kohrman M. 2015. Transdermal nicotine patch as a novel treatment for epilepsy associated with a mutation in the nicotinic acetylcholine receptor (S35. 002). AAN Enterprises, Minneapolis.

SoRelle JA, Thodeson DM, Arnold S, Gotway G, Park JY. 2018. Clinical utility of reinterpreting previously reported genomic epilepsy test results for pediatric patients. JAMA Pediatr e182302. doi:10.1001/jamapedi atrics.2018.2302

Spacey S. 1993. Episodic ataxia type 2. In GeneReviews ${ }^{\circledR}$ (ed. Adam MP, et al.). University of Washington, Seattle, WA. https://www.ncbi.nlm.nih.gov/books/NBK1501/

Stewart JD, Horvath R, Baruffini E, Ferrero I, Bulst S, Watkins PB, Fontana RJ, Day CP, Chinnery PF. 2010. Polymerase $\gamma$ gene POLG determines the risk of sodium valproate-induced liver toxicity. Hepatology 52: 1791-1796. doi:10.1002/hep.23891

Strom SP, Lee H, Das K, Vilain E, Nelson SF, Grody WW, Deignan JL. 2014. Assessing the necessity of confirmatory testing for exome-sequencing results in a clinical molecular diagnostic laboratory. Genet Med 16: 510-515. doi:10.1038/gim.2013.183

Tan TY, Dillon OJ, Stark Z, Schofield D, Alam K, Shrestha R, Chong B, Phelan D, Brett GR, Creed E, et al. 2017. Diagnostic impact and cost-effectiveness of whole-exome sequencing for ambulant children with suspected monogenic conditions. JAMA Pediatr 171: 855-862. doi:10.1001/jamapediatrics.2017.1755

Trivisano M, Specchio N, Vigevano F. 2015. Extending the use of stiripentol to other epileptic syndromes: a case of PCDH19-related epilepsy. Eur J Paediatr Neurol 19: 248-250. doi:10.1016/j.ejpn.2014.11.008

Tsuchida N, Nakashima M, Kato M, Heyman E, Inui T, Haginoya K, Watanabe S, Chiyonobu T, Morimoto M, Ohta $\mathrm{M}$, et al. 2018. Detection of copy number variations in epilepsy using exome data. Clin Genet 93: 577-587. doi:10.1111/cge.13144

Vissers L, van Nimwegen KJM, Schieving JH, Kamsteeg EJ, Kleefstra T, Yntema HG, Pfundt R, van der Wilt GJ، Krabbenborg L, Brunner HG, et al. 2017. A clinical utility study of exome sequencing versus conventional genetic testing in pediatric neurology. Genet Med 19: 1055-1063. doi:10.1038/gim.2017.1

Vlaskamp DRM, Callenbach PMC, Rump P, Giannini LAA, Dijkhuizen T, Brouwer OF, van Ravenswaaij-Arts CMA. 2017. Copy number variation in a hospital-based cohort of children with epilepsy. Epilepsia Open 2: 244-254. doi:10.1002/epi4.12057

Wang J, Gotway G, Pascual JM, Park JY. 2014. Diagnostic yield of clinical next-generation sequencing panels for epilepsy. JAMA Neurol 71: 650-651. doi:10.1001/jamaneurol.2014.405

Yang Z, Yang X, Wu Y, Wang J, Zhang Y, Xiong H, Jiang Y, Qin J. 2014. Clinical diagnosis, treatment, and ALDH7A1 mutations in pyridoxine-dependent epilepsy in three Chinese infants. PLoS ONE 9: e92803. doi:10.1371/journal.pone.0092803

Zerem A, Nishri D, Yosef Y, Blumkin L, Lev D, Leshinsky-Silver E, Kivity S, Lerman-Sagie T. 2013. Resolution of epileptic encephalopathy following treatment with transdermal nicotine. Epilepsia 54: e13-e15. doi:10 $.1111 / j .1528-1167.2012 .03715 . x$ 


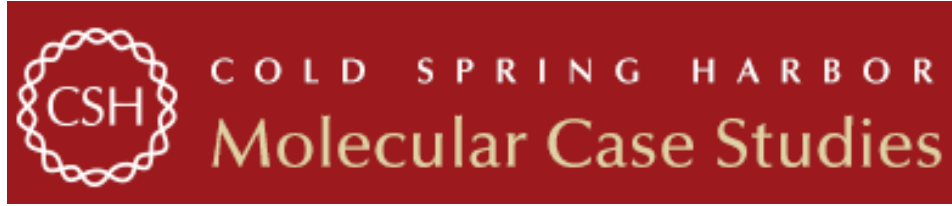

\section{Genomic testing in pediatric epilepsy}

Drew M. Thodeson and Jason Y. Park

Cold Spring Harb Mol Case Stud 2019, 5: a004135

Access the most recent version at doi: $10.1101 /$ mcs.a004135

References This article cites 73 articles, 7 of which can be accessed free at: http://molecularcasestudies.cshlp.org/content/5/4/a004135.full.html\#ref-list-1

License This article is distributed under the terms of the Creative Commons Attribution-NonCommercial License, which permits reuse and redistribution, except for commercial purposes, provided that the original author and source are credited.

Email Alerting Receive free email alerts when new articles cite this article - sign up in the box at the Service top right corner of the article or click here. 